\title{
Histopathological pattern of skin cancer at tertiary referral skin health centre
}

\author{
Ram Chandra Adhikari ${ }^{1,4}$, Mahesh Shah ${ }^{2,4}$, Anil Kumar Jha ${ }^{3,4}$ \\ ${ }^{I}$ Department of Pathology, Tribhuvan University Teaching Hospital, Kathmandu, Nepal \\ ${ }^{2}$ Anandaban leprosy hospital, Anandaban, Lalitpur, Nepal \\ ${ }^{3}$ Department of Dermatology, Nepal Medical College Teaching Hospital, Attarkhel, Kathmandu, Nepal \\ ${ }^{4}$ DI Skin Health \& Referral Centre, Maharajgunj, Kathmandu, Nepal
}

\section{Keywords:}

Adnexal tumor;

Basal cell carcinoma;

Cancer;

Skin;

Metastasis;

\begin{abstract}
Background: The skin is a heterogeneous organ, capable of producing various types of skin tumors. The incidence of skin cancers, including melanoma and non-melanoma has been reported to have risen in many parts of the world. In Asian and African countries, individuals with pigmented races have a much lower incidence of skin cancers despite sunny hot weather. This study is aimed to analyze age, sex and site wise of distribution of skin cancers.

Materials and Methods: The study included a total of 60 patients with histopathologically proven skin cancers from January 2015 to December 2018 in the department of pathology, DI skin health and referral centre, Kathmandu, Nepal.

Results: A total of 60 cases of histopathologically proven skin cancer constituted $3.69 \%$ of total skin biopsies. Patient age ranged from 15 to 88 years with mean age being 61 years. The majority of the patients were in the age group of 61-70 yrs. The male to female ratio is 1:1.3. Basal cell carcinoma was the most common skin cancer constituting $43.4 \%$, followed by squamous cell carcinoma (28.3\%). The most common site of skin cancer is head \& neck (73.3\%), followed by lower extremities (8.3\%). Other skin cancers were Bowen's disease, melanoma, verrucous carcinoma, keratoacanthoma, trichilemmal carcinoma, extramammary Paget's disease, Non-Hodgkin lymphoma and metastatic tumor.
\end{abstract}

Conclusion: The most common type of skin cancer is basal cell carcinoma, followed by squamous cell carcinoma and head \& neck being the commonest site.

\section{Correspondence:}

Dr. Ram Chandra Adhikari, $M D$

Professor, Department of Pathology,

Tribhuvan University Teaching Hospital, Maharajgunj, Kathmandu, Nepal ORCID ID: 0000-0002-1605-2898

Email: rcadhikari@hotmail.com

Reveived : August 19 2019 ; Accepted : September $15^{\text {th }} 2019$

Citation: Adhikari RC, Shah M, Jha AK. Histopathological pattern of skin cancer at tertiary referral skin health centre. J Pathol Nep 2019;9:1555-9. DOI DOI 10.3126/jpn.v9i2.25827

Copyright: This is an open-access article distributed under the terms of the Creative Commons Attribution 4.0 International License, which permits unrestricted use, distribution, and reproduction in any medium, provided the original author and source are credited.

\section{INTRODUCTION}

The skin is a heterogeneous organ with varied elements of ectodermal and mesodermal origin, capable of producing various types of skin tumors. ${ }^{1}$ Though inflammatory dermatoses form the bulk of diseases in a tropical and developing country like Nepal, the incidence of skin cancers, including melanoma and non-melanoma has been reported to have risen in many parts of the world with the highest incidence in locations such as United states, Europe, Australia, and New Zealand. ${ }^{2,3}$ In the United states, it is increasing by about $2 \%$ per year. ${ }^{4}$ In Asian and African countries, it is known that pigmented races have 
a much lower incidence of skin cancers despite sunny hot weather than do Caucasian races. ${ }^{5}$ Sunlight exposure is considered to be an important risk factor for epidermal damage and malignancy. The sun-related cancers like basal cell carcinoma, squamous cell carcinoma, and malignant melanoma are the commonest cancers worldwide. ${ }^{6}$

The true incidence and clinicopathological characteristic features of skin cancers in Nepal are not established. In addition, there are no well-developed programs for skin self-checking, protection, and screening. These factors may delay detection and diagnosis and contribute to the low number of skin malignancy cases.

This retrospective study was performed to analyze the pattern of skin cancers seen at DI skin health and referral centre (DISHARC), Kathmandu, Nepal over the last four years and to determine age, sex, and site-wise of distribution of skin cancers.

\section{MATERIALS AND METHODS}

The study was done from January 2015 to December 2018 in the department of pathology, DI skin health and referral centre (DISHARC), Kathmandu, Nepal. This study included a total of 60 patients with histopathologically proven skin cancers from the record of pathology at DISHARC. The specimens were formalin-fixed, processed in automated histokinette, sectioned and stained with Hematoxylin \& eosin and reviewed by a pathologist. Immunohistochemical stainings were done whenever required and for this purpose, paraffin blocks were sent to Zurich, Switzerland. Relevant data on the incidence, age, sex, and sites were crosstabulated.

\section{RESULTS}

A total of 1625 skin biopsies was received in the department of Pathology during the study period and 60 cases of them were proved to be skin cancer with the frequency being
$3.69 \%$. The patient's age ranged from 15 to 88 years with the mean age being 61 years. The majority of the patients were in the age group of 61-70 yrs (Table 1). There was a slight female predominance for skin cancers $(56.7 \%$ vs $43.3 \%$ ) with a male to female ratio of $1: 1.3$.

Histopathological diagnoses of skin cancer are shown in Table 2. Basal cell carcinoma (BCC) was the most common skin cancer (Figures $1 \& 2$ ) constituting 43.4\%, followed by squamous cell carcinoma (SCC) $(28.3 \%)$. According to

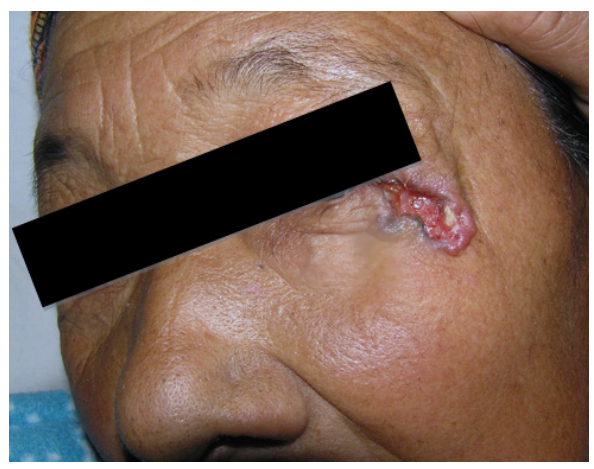

Figure 1: Ulcerative lesion of basal cell carcinoma involving the lower eyelid and lateral canthus. Consent from the patient was obtained for publication of the image

Table 1: Age distribution of patients with skin cancer

\begin{tabular}{lc}
\hline Age group (in years) & Number of cases (\%) \\
\hline $0-10$ & $0(0.00)$ \\
$11-20$ & $4(6.67)$ \\
$21-30$ & $1(1.67)$ \\
$31-40$ & $4(6.67)$ \\
$41-50$ & $5(8.33)$ \\
$51-60$ & $9(15.00)$ \\
$61-70$ & $15(25.00)$ \\
$71-80$ & $12(20.00)$ \\
$>80$ & $10(16.66)$ \\
\hline Total & $\mathbf{6 0}(\mathbf{1 0 0 . 0 0 )}$ \\
\hline
\end{tabular}

Table 2: Histopathological diagnoses of patients with skin cancer

\begin{tabular}{lccc}
\hline Histopathological diagnoses & Number of cases (\%) & Mean age (Yrs) & Male/Female \\
\hline Basal cell carcinoma & $26(43.4)$ & 63.6 & $10 / 16$ \\
\hline Squamous cell carcinoma & $17(28.3)$ & 59.6 & $10 / 7$ \\
\hline Bowen's disease & $4(6.7)$ & 49.7 & $2 / 2$ \\
Extramammary Paget's disease & $3(5.0)$ & 63.3 & $2 / 1$ \\
\hline Keratoacanthoma & $2(3.3)$ & 72.5 & $1 / 1$ \\
Melanoma & $2(3.3)$ & 58.0 & $0 / 2$ \\
Non-Hodgkin lymphoma & $2(3.3)$ & 63.5 & $0 / 2$ \\
Metastatic tumor & $2(3.3)$ & 55.0 & $1 / 1$ \\
Verrucous carcinoma & $1(1.7)$ & 66.0 & $0 / 1$ \\
Trichilemmal carcinoma & $1(1.7)$ & 59.0 & $0 / 1$ \\
\hline Total & $\mathbf{6 0 ( 1 0 0 . 0 )}$ & $\mathbf{6 1 . 0}$ & $\mathbf{2 6 / 3 4}$ \\
\hline
\end{tabular}




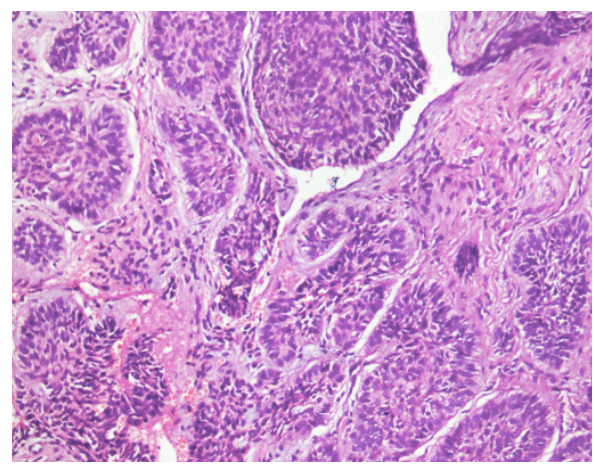

Figure 2: Basal cell carcinoma, nests of basaloid cells infiltrating the dermis (HE stain, X200).

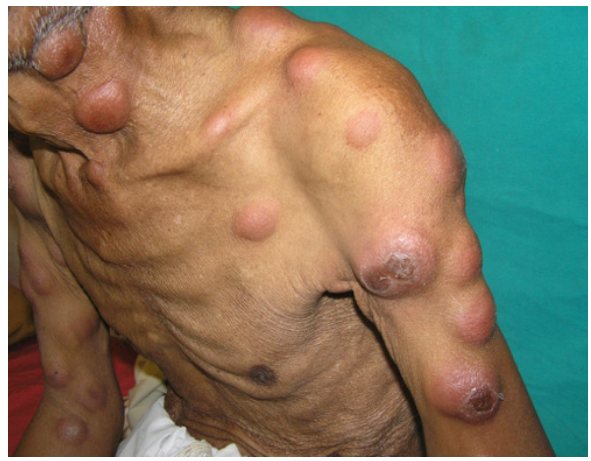

Figure 4: Nodular lesion of cuataneous T-cell lymphoma.

the sites (Table 3), the most common site of skin cancer is head \& neck (73.3\%), followed by lower extremities (8.3\%). Out of 26 basal cell carcinoma cases, 25 were located in the head \& neck region. The most common site of squamous cell carcinoma (Figure 3 ) is also head \& neck. Other skin cancers were Bowen's disease, melanoma, verrucous carcinoma, keratoacanthoma, Trichilemmal

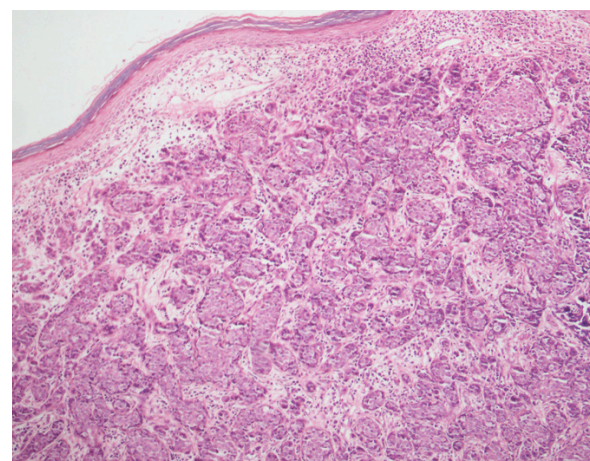

Figure 3: Squamous cell carcinoma, nests of atypical squamoid cells infiltrating the dermis (HE stain, X100).

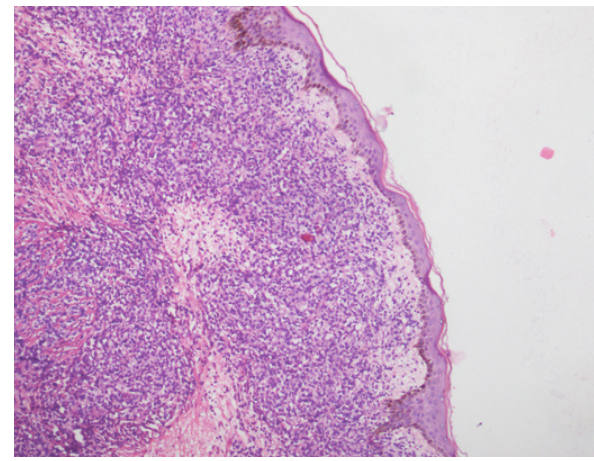

Figure 5: Cutaneous Non-Hodgkin lymphoma showing diffuse dermal infiltrate of neoplastic lymphoid cells (HE stain, X40).

carcinoma, extramammary Paget's disease, Non-Hodgkin lymphoma (Figures $4 \& 5$ ) and metastatic tumor. Cases of keratoacanthoma and Trichilemmal carcinoma were also found in the head \& neck region. There were two cases of metastatic tumors, one being metastatic chondrosarcoma and another invasive lobular carcinoma.

Table 3: Site wise distribution of skin cancers

\begin{tabular}{|c|c|c|c|c|c|c|c|c|c|}
\hline \multirow{2}{*}{ HISTOPATHOLOGICAL DIAGNOSIS } & \multicolumn{9}{|c|}{ Sites } \\
\hline & $H \& N^{*}$ & Chest & Back & $\mathbf{U E} \dagger$ & $\mathbf{L E}+\dagger$ & EG** & Axilla & Groin & Total \\
\hline Basal cell carcinoma & 25 & & 1 & & & & & & 26 \\
\hline Squamous cell carcinoma & 15 & & & & 2 & & & & 17 \\
\hline Bowen's disease & & & & & & 4 & & & 4 \\
\hline Extramammary Paget's disease & & 1 & & & & & 1 & 1 & 3 \\
\hline Keratoacanthoma & 2 & & & & & & & & 2 \\
\hline Melanoma & & & & & 2 & & & & 2 \\
\hline Non-Hodgkin lymphoma & 1 & 1 & & & & & & & 2 \\
\hline Metastatic tumor & & 1 & & 1 & & & & & 2 \\
\hline Verrucous carcinoma & & & & & 1 & & & & 1 \\
\hline Trichilemmal carcinoma & 1 & & & & & & & & 1 \\
\hline Total & 44 & 3 & 1 & 1 & 5 & 4 & 1 & 1 & 60 \\
\hline
\end{tabular}

$H \& N^{*}$ : Head \& neck; UE \%: Upper extremities; LE††: Lower extremities; EG: External genitalia 


\section{DISCUSSION}

Skin cancers are not an uncommon malignancy in Nepal and there is a growing number of skin malignancy reported from different regions of Nepal. ${ }^{7,8}$ These studies have reported different types of skin cancers including BCC, SCC, and melanoma. The incidence of non-melanoma skin cancer (BCC \& SCC) is much more common than melanoma in this study and other studies of Nepal., 2014 WHO report clearly stated that skin cancer is the most common cancer worldwide. ${ }^{9}$ The incidence of non-melanoma skin cancers (BCC \& SCC) is more than three times that of other cancers in Australia ${ }^{10}$ and is higher than that of any other cancers in the USA. ${ }^{11}$ This finding is not consistent in the context of Nepal.

During the study period, BCC was the most frequently diagnosed skin cancer, followed by SCC. This finding is consistent with other studies from $\mathrm{Asia}^{6,12,13}$ and in Caucasian populations. ${ }^{14}$ Both BCC and SCC arised in the skin of head \& neck in this study and same found in other studies. ${ }^{12,13}$ This area of the body is most exposed to the sun and ultraviolet light exposure is the main environmental etiological factor for these tumors. Ultraviolet rays act by inducing DNA mutations and immunosuppression, leading to uncontrolled growth and tumor formation. ${ }^{15}$ Mean age of patients with BCC was 63.6 years and that of SCC was 59.6 years, which is similar to the study of Albasri AM et al. ${ }^{12}$

There were 4 (6.7\%) cases of Bowen's disease in this study; all of them were found in external genitalia. In a study of Tham SN et al. ${ }^{13}$, the commonest site of Bowen's disease is upper extremities, followed by trunk. The possible etiological factor blamed to cause this disease in that study was arsenic exposure. The mean age of patients with Bowen's disease is 49.7 years in this study, while it is 62.7 years in other study. ${ }^{12}$ We have seen a case of verrucous carcinoma in the lower extremity, two cases of keratoacanthoma and a case of trichilemmal carcinoma in head \& neck region.

Extramammary Paget's disease is a rare entity and may be found in flexural skin of multiple sites like vulva, penis and scrotum. ${ }^{16}$ Our cases were located in groin, axilla and chest and mean age is 63.3 years.

Malignant melanoma is a much rarer diagnosis ranking fifth common skin cancer constituting 3.3\% in this study. This finding conflicts with the reports from countries like Australia and USA; however, it is consistent with the findings of Asian countries. ${ }^{6,12,13}$ In this study, there were 2 cases of malignant melanoma, one being acral melanoma (sole) and another low-CSD melanoma (thigh). Mean age of patients with melanoma in this study is 58 years, which is younger than mean age of patients in non-melanoma (BCC \& SCC). Similar observation was reported in a study of Omari AK et al. ${ }^{6}$ The nature of the exposure to sunlight necessary for the development of melanoma appears to differ from that for non-melanoma skin cancer. It has been shown that the risk of melanoma increases with history of sunburn, particularly in childhood and migration to sunny areas, especially during childhood was seen to increase its incidence. ${ }^{17}$ Other studies stated the incidence of melanoma to be higher in higher socioeconomic groups and indoor workers, and less in areas of maximum light exposure like face, being most common on the back in men and on lower limbs in women. ${ }^{18,19}$ Lower extremity is the site of melanoma in this study and this finding is consistent with other studies.

Two cases of cutaneous lymphoma were reported in this study and the rarity of this tumor found in this study is quite similar to other studies. ${ }^{6,12}$

The skin is not a common site for metastasis. However, We found a case of metastatic chondrosarcoma and a case of metastatic invasive lobular carcinoma (breast). Albasri AM et al reported metastatic adenocarcinoma of the skin. This study highlighted the frequency of skin cancer from the tertiary referral centre of Nepal and it does not necessarily reflect the true incidence of skin cancer of the country. This may be considered to be a limitation of this study.

\section{CONCLUSION}

The most common type of skin cancer is basal cell carcinoma, followed by squamous cell carcinoma and head $\&$ neck being the commonest site. Malignant melanoma is a rare skin neoplasm with a predilection for the acral location.

\section{Conflict of interest: None}

\section{REFERENCES}

1. Gloster HM Jr., Neal K. Skin cancer in skin of color. J Am Acad Dermatol 2006; 55: 741-60. $\underline{\text { Crossref }}$

2. Ferloy J, Soerjomataram I, Dikshit R, Eser S, Mathers C, Rebelo $\mathrm{M}$ et al. Cancer incidence and mortality worldwide: Sources, Methods and major patterns in GLOBOCAN 2012. Int J Cancer 2014; 810: 120-40. Crossref

3. Leiter U, Eigentler T, Garbe C. Epidemiology of skin cancer. Adv Exp Med Biol 2014;810:120-40. Crossref

4. Glass AG, Hoover RN. The emerging epidemic of melanoma and squamous cell skin cancer. JAMA 1989; 262: 2097-100. Crossref

5. Jacobs RH, Ripey JJ, Altini M. Prediction of aggressive behavior in basal cell carcinoma. Cancer 1982; 49: 533-7. Crossref 
6. Omari AK, Khammash MR, Matalka I. Skin cancer trends in northern Jordan. Int J Dermatol 2006; 45: 384-8. Crossref

7. Kumar A, Shrestha PR, Pun J, Thapa P, Manandhar M, Sathian B. Profile of skin biopsies and patterns of skin cancer in a tertiary care centre of western Nepal. Asian Pac J Cancer Prev 2015; 16: 3403-6. Crossref

8. Adhikari RC, Shah M, Jha AK. Histopathological spectrum of skin diseases in a tertiary skin health and referral centre. Journal of Pathology of Nepal 2019;9:1434-40. Crossref

9. Stewart BW, Wild CP. World cancer report, Geneva: World Health Organization; 2014. ( Cited on 10th July 2019). Crossref

10. Marks R. Epidemiology of non-melanoma skin cancer and solar keratosis in Australia: a tale of self-immolation in Elysian Fields. Australas J Dermatol 1997;38:526-9. Crossref

11. Martinez JC, Otley CC. The management of melanoma and nonmelanoma skin cancer: a review for the primary care physician. Mayo clinic Proc 2001; 76:1253-65. Crossref

12. Albasri AM, Borhman WM. Histopathological pattern of skin cancer in Western region of Saudi Arabia. An 11 years experience. Saudi Med J 2018;39:994-8. Crossref
13. Tham SN, Goh CL. Skin cancer at tertiary referral skin hospital in Singapore. Int J Dermatol 1995;34:770-6. Crossref

14. Urbach F. Incidence of nonmelanoma skin cancer. Dermatol Clin 1991;19: 751-5. Crossref

15. Gloster H, Neal K. Skin cancer in skin of color. J Am Acad Dermatol 2006; 55: 741-60. Crossref

16. Wolf K, Stewart L, Rapini R, Mutyambizi K. Multifocal extramammary Paget's disease-associated adenocarcinoma: a rare condition of flexoral skin of multiple sites. Dermatol Online J 2016; 22: pii: 13030/qt8bp3138w. Crossref

17. Marks R. An overview of skin cancers. Incidence causation. Cancer 1995;75:607-12. Crossref

18. Holman CDJ, Mulroney CDD, Armstrong BK. Epidemiology of pre-invasive and invasive malignant melanoma in Western Australia. In J Cancer 1980; 25:317-23. Crossref

19. Cooke KR, Skegg DCG, Fraser J. Socioeconomic status, indoor and outdoor work and malignant melanoma. Int $\mathrm{J}$ Cancer 1984; 34: 57-61. Crossref 